\title{
Muslim Selbstverständnis: Ahmet Davutoğlu Answers Husserl's Crisis of European Sciences
}

\author{
SCOTT MORRISON ${ }^{1}$
}

\begin{abstract}
In formulating his understanding of Islamic history, thought and politics, the Turkish Muslim thinker Ahmet Davutoğlu adopts the German philosopher Edmund Husserl's formulation of phenomenology - or, philosophy of consciousness. Both Husserl and Davutoğlu perceive a crisis in humanity and identify its causes in scientism and logical positivism, against which they develop their respective phenomenological alternatives. This article places in parallel Husserl's stylised history of Western thought and Weltanschauung method with that of Davutoğlu's Muslim worldview, in order to illuminate the latter's putatively comprehensive interpretation of Islam, diagnosis of the ills of secularism, modernisation, and crisis of values he finds in Muslim societies; and his prescribed treatment for those ills: the privileging of ontology over epistemology, and the full unfolding of core theological concepts of revelation, monotheism, and prophecy. Davutoğlu seeks to reconcile tensions and disputes within Islamic intellectual traditions concerning the nature of God and God's attributes, and the tension between mysticism and rationalism, and the historical and the atemporal. In summary, Davutoğlu's intervention in Islamic traditions is interesting in the effort it makes to appropriate elements of both Husserl and GWF Hegel for the purpose of reconciling a phenomenological reading of Islam with established Islamic authorities and commitments.
\end{abstract}

Keywords: Ahmet Davutoğlu, Edmund Husserl, phenomenology, Weltanschauung

In a lecture he delivered in Vienna in May 1935 (Biemel 1962) the German philosopher Edmund Husserl identified a crisis in the West (which he defined as Europe, Britain and the US). More precisely he found multiple crises, which he termed the crises of the European sciences (krises de europäisichen Wissenschaften). The content of the Vienna lecture reveals a crisis that was precipitated by the European sciences and that afflicted all of European humanity (Europaischen Menschheit). Husserl traced the origins of this crisis of humanity to the work of the Italian physicist and founding theorist of science Galileo Galilei. Galileo's conception of the universe as a closed, logical, and mechanical system was, Husserl believed, the force behind the empirical, positivistic excesses of modern science which wrought the crisis. He also blamed the Renaissance which, like Galileo, had unduly elevated humanity and exaggerated the powers of the human mind. No opponent of rationalism, Husserl objected to the fact that in the West, rationalism had been rendered superficial, in its entanglement in 'naturalism' and 'objectivism' (Carr 1970: 299). European humanity was alienated from itself. It had grown distant from that which had made it special and admirable: its role as a philosophical and a critical agent exploring not only the capacity but also the limitations of reason and rationality.

\footnotetext{
${ }^{1}$ Scott Morisson, Ph.D., Assoc. Professor at Akita University, Tegata Gakuen-cho 1-1, AKITA CITY, Akita Prefecture, 010-8502 Japan, email: smsmorrison@gmail.com; morrison@gipc.akita-u.ac.jp.
} 
Ahmet Davutoğlu, a Muslim, Turkish academic turned government adviser and (since 2009) the Foreign Minister of the Turkish Republic, answers Husserl's European crisis with his doctoral dissertation, published in 1994 as Alternative Paradigms: The Impact of Islamic and Western Weltanschauungs on Political Theory. In this work Davutoğlu agrees with Husserl's diagnosis of the West. Davutoğlu accepted Husserl's diagnosis of the aetiology and symptoms of the European crisis. His prescription, however, was one that Husserl did not consider: Islamic civilisation (Íslam medeniyeti). Treating the Western worldview as a fatally-flawed foil, Davutoğlu reads the history of Islamic traditions as the only available cure to the ailments of Western civilisation. Whilst an assertion such as this is a certain recipe for civilisational competition and conflict, the purpose of bringing Husserl and Davutoğlu into dialogue is rather to explore a tendency common to the intellectual workings of each figure: the phenomenological impulse.

It is evident as a matter of historical fact that Husserl was not a Muslim and that his philosophical ideas did not originate in Islam. Whatever his religious identity Husserl did conceive and practise a philosophical school he explicitly termed phenomenology; a philosophy of consciousness that eschewed pretensions to unmediated, objective truths and claims about a mind-independent world, external to consciousness. Whether Davutoğlu subscribed to Husserl's phenomenology and discovered the same transcendental impulses independently evolved in his own religious faith is unclear; the question is secondary. This article explores instead the question whether Islam - as interpreted and adumbrated by Ahmet Davutoğlu - is itself an earlier, and continuing, latent instance of phenomenology.

\section{From Umwelt to Lebenswelt}

Although Husserl emphasised in his lecture that he did not intend reference to the West to be understood in geographic terms, it is apparent that he considered Greece in the sixth and seventh centuries BCE to be its birthplace. The philosopher Plato extracted (Western) humanity from the Umwelt. This term of Husserlian art, the Umwelt is the pre-theoretical world in which naïveté rules, perceptions are immediate, and reality is neither more nor less than it seems. For the philosophers at least Plato inaugurated the search for things as they really are, appearances notwithstanding; the world was not what it seemed, and sensory perceptions are even yet neither accurate nor sufficient guides to truth. As Husserl describes Plato's discoveries: because reality is something other than is immediately apparent, Representations (Weltvorstellung) become necessary - representations of true reality which is not accessible through the sensible organs of perception (Carr 1970: 293). Representations allow humanity to momentarily escape the world of appearance, to begin contemplating eternal truths. Husserl told his audience in Vienna that with the intervention of Plato and his student Aristotle 'a remarkable split makes itself felt; the human belongs to the sphere of objective facts, but as persons, as egos, men have goals, ends, norms given by the tradition, norms of truth - eternal norms' (Carr 1970: 293-294). The tradition is the West, delivered from the Umwelt, liberated by imagination, and aided by representation to live the philosophical life.

With this exit from the Umwelt, Western humanity entered the Lebenswelt - the lifeworld, or the world in which humanity lived together in philosophical awareness. In that society, philosophy constituted man's infinite task. Within the infinite task, man found his finite task and his place in the universe: his Selbstverständnis, defined as the human awareness and understanding of self; and at the same instant Western humanity's identity as Western or European. The Western Selbstverständnis is the ultimate 'self-understanding as being in being called to a life of apodicticity' (Carr 1970: 340-341). Apodicticity denotes propositions that are susceptible of definitive proof and logical certainty. Apodicticity is not restricted to abstract thought or philosophy; it is a process through which Western humanity realises itself 'in 
apodictic freedom' living 'the whole active life of its reason' (Carr 1970: 340-341) in the Lebenswelt.

\section{Muslim Selbstverständnis}

Philosophy and reason are infinite but as a finite being mankind can only undertake a finite task. Davutoğlu adopts the appropriation of Husserl by an Orientalist observer of Islam, von Grunebaum, who re-inscribes Selbstverständnis onto a spiritual, if not an overtly religious, template. Von Grunebaum substitutes the broader category of rationality for philosophy; the pursuit of rationality furnishes humanity its task. Just as Plato took a step forward thereby straddling Umwelt and Lebenswelt, humanity steps into the eternal realm: this step and the psychological operation that accompanies it signifies an infinity of living and striving toward reason; that reason is precisely that which man qua man, in his innermost being, is aiming for, that which alone can satisfy him, make him 'blessed' (Von Grunebaum 1962: 105). Whether Von Grunebaum embellishes in a pious register not entirely consonant with Husserl, the notion of being blessed - as opposed to more fully human or Western - is an open question.

According to Husserl, the purpose of history is not knowledge of the past for its own sake, but rather 'to see and understand ourselves', and by such Selbstverständnis 'to find our specific task within the infinite task' (Gurwitsch 1956: 385). Even as Husserl and Davutoğlu each seek to transcend the Lebenswelt, neither denies history nor the nature of humanity as an undeniably historical being. Husserl speaks for both men:

History does not denote a past behind us and extraneous to us. On the contrary, the past is contained and implied within our present. Our intentions as philosophers of the present age continue, and are in continuity with, the intentions of our intellectual ancestors, because we not only possess a historical heritage but are historical beings throughout (Gurwitsch 1956: 387).

Husserl did not counsel return to any earlier philosophical system. He sought to revive philosophy through his phenomenology. Davutoğlu repeatedly emphasises that the field of history is the locus of Islam's revelation and unfolding. He substitutes Muslims for philosophers in Von Grunebaum's reiteration of Husserl's Selbstverständnis, revealing the parallel purposes each of the three authors pursue and counsel: Husserl's historico-teleological reflections are meant to enable us, the contemporary philosophers [Muslims], to see and to understand ourselves (Selbstverständnis) that is to find our specific task within the infinite task. Through such reflections, the historical context of philosophy is to be revivified, so that we may become aware of our place within that context and of the specific task which is assigned to us at that place (Gurwitsch 1956: 385). To Davutoğlu, becoming Muslim means the gradual adoption of the self-conception and worldview of Islam. The surrender of self required of a faithful person, the constraints piety imposes, and the link that consequently connects Muslim and Islam; the core acts and effects of affiliation share with a phenomenological philosopher a determined, dutiful mission. Grasping the close relationship between Weltanschauung and civilisation (e.g. Islamic civilisation - Íslam medeniyeti - as that theme recurs in Davutoğlu's writings since 1994) is essential to understanding his system of thought and his personal position within that system. Weltanschauungen are both products and features of the civilisation (whether Western or Islamic) from which they issue. Weltanschauungen lead a double life. They are both factualhistorical and teleological. Like every philosophy or philosophical school, a Weltanschauung is a historical fact. However, 'in the development of humanity's life of the spirit it has a greater, even unique teleological function, that of being the highest elevation of the life experience, education, and wisdom of its time' (Husserl 1981: 189). 
Accordingly, when Davutoğlu sets out to articulate the Islamic Weltanschauung he does not purport to express his own opinions, but rather the product of Muslim world history comprehensively construed - the telos of Islam as evidenced at that moment. As author he seeks to subsume himself in his subject; arguably the success of his project (or at least that portion of it which seeks to command the agreement of committed Muslim readers) rests on the extent to which he succeeds in doing so.

\section{A Transplanted Crisis}

Davutoğlu does not deny that the crisis Husserl identified in his Vienna lecture has seized Muslim majority society. He simply denies that the crisis is of Muslims' making - apart from Muslim Westernisers under the same mistaken commitments as Westerners themselves. He asserts that the means of resolving the crisis are available, as they have been since the advent of Islam. While he speaks nostalgically - even apologetically - of the Ottoman Empire, he places Muslim modernisers in Turkey, led by Mustafa Kemal, in the thrall of the Western worldview and therefore considers them unwilling or unable to understand much less adopt the Islamic worldview. The crisis of legitimacy that Davutoğlu perceives in the Turkish Republic (the successor nation-state to the Ottoman Empire) is in his opinion an inevitable result of the official secular ideology of Kemalism (Davutoğlu 1999: 7; Mardin 1989: 227). In other writings (Davutoğlu 1994b) including his best known work - on international relations theory (Davutoğlu 2001) - Davutoğlu, fully deploys the notion of civilisation(s) and civilisational units, and he goes so far as to accept Samuel Huntington's analysis of the Turkish Republic as a 'torn' country - torn between the West and Islam (Davutoğlu 2002: 137). According to Davutoğlu, due to the schism cleaving the Republic since its foundation, Turks are trapped in an inauthentic polity, sometimes resisting and sometimes acquiescing to the blandishments of an essentially alien Western worldview. In consequence Davutoğlu does not deny the applicability of Husserl's 1935 pronouncement of European crisis to Turkey. Furthermore he concurs that the crisis of humanity afflicts in equal measure the Western and the Muslim worlds due to the impact of Western forces - principally colonialism and imperialism - on Muslims and within Muslim majority societies.

The differences between Islamic and Western worldviews are nevertheless fundamental, and are essentially consistent in their depiction by Davutoğlu whether he is writing about international relations theory or religious thought. And those differences originate from the respective 'philosophical, methodological, and theoretical background rather than from mere institutional and historical differences' (Davutoğlu 1994a: 2) that distinguish Islam from the West. The differences between Western and Islamic world views explain 'sociopolitical resistance among Muslim masses and elites against Western ways of life and political structures' (Davutoğlu 1994a: 78) and the phenomenon of Islamic revivalism over the last three or four decades. The causal arrow cannot be reversed. There is evidently not inconsiderable agreement between Davutoğlu and Samuel Huntington concerning the existence and probable interactions of discrete global civilisations.

Davutoğlu opposes the actual or the attempted imposition of the Western worldview onto Muslim peoples, whether at the insistence of Western people engaged in (neo-)imperialist enterprises, or Muslims themselves in misguided modernisation efforts. For this reason he views the efforts of nineteenth century Islamic modernists such as Jamal al-Din al-Afghani, Muhammad `Abduh, and Rashid Rida as incomplete and superficial. He is in a literal sense a post-Islamic modernist. Islamic modernists in his assessment adopted an institutional approach to a philosophical problem, dooming their efforts to futility - much as it would be futile to attempt to exorcise a ghost in a machine using a screw-driver. The inexorable (in his opinion) failure of the modernists and the modernising and nationalist projects that they initiated 
opened the way for more responsive and relevant, and potentially more effective forms of thought and action:

The modernists expected that the new institutional framework would necessarily transform the traditional self-perception and mentality of the Islamic civilisation. This expectation, however, did not come true. On the contrary, self-confidence has grown and Islamic identity has revived using modern forms and structures (Davutoğlu 2000: 189).

In Davutoğlu's perception, in the Arab Middle East and the greater Muslim world, modernisers and Islamic modernists failed to appreciate the distinctive character and persistence of the Islamic worldview, dooming their efforts at advancing Muslims in the world. (Davutoğlu 1994a: 7; Davutoğlu 2000: 189). Efforts by outside colonial or neo-imperial forces also failed to completely transform the Muslim Weltanschauung, although they were not without some apparent efficacy in torn countries such as Turkey, although in the Turkish case the agents of Westernisation were indigenous. Nevertheless, efforts to secularise the Muslim world are destined to fail, he says: "The secularisation process in the Muslim world was not able to change the worldview in the mind of a Muslim" (Davutoğlu 2000: 189). The crisis to which Husserl refers, then, has arisen in the Muslim world, but only to the extent that Muslims have been subjugated or have submitted themselves to the Western Weltanschauung. Rather than paper over those characteristics that distinguish the Islamic from the Western Weltanschauung, Davutoğlu accentuates those differences and (re-)draws a notional civilisational boundary between Islam and the West. This conflict of Weltanschauungen is also implicated in the contradictory self-understandings of two sub-species of Homo Sapiens: Homo Orientalis and Homo Occidentalis, respectively; the Selbstverständnises of this pair of subspecies place them at odds with one another. The postulated adversarial relation, and its confirmation by Davutoğlu, is not lacking in irony when account is taken of the use to which Davutoğlu puts Edmund Husserl's phenomenological innovations.

\section{Lebenswelt to Phenomenology, via Descartes}

Epoché is an ancient Greek word meaning 'to bracket' (Hammond et al. 1991: 4). Epoché is a setting aside, a suspension of a conviction, perception or premise. Husserl appropriates the term to name a philosophical technique, the invention of which he credits Plato. Plato engaged the first epoché when he overcame the Umwelt and entered the Lebenswelt. The second epoché Husserl attributes to Descartes, with his discovery and philosophical use of the concept of consciousness. In the Cartesian moment, with the recognition of the conscious subject, a distinctive metaphysics and epistemology become possible - one mediated by the subject, the ego. According to Husserl, the Cartesian epoché bracketed everything but consciousness, with the result that:

\footnotetext{
Mundane existents are, however, no longer simply accepted as they are in the natural attitude. Rather they are regarded as experienced entities, to be taken exactly as they appear; they are considered as entities presenting themselves as real, etc. All mundane existents and the Lebenswelt as a whole are transformed into phenomena in the specific sense of being referred to the acts of consciousness through which they are given, and of being taken exactly as they stand before the mind of the subject experiencing those acts (Gurwitsch 1956: 380).
}

Husserl treats Descartes as an incipient phenomenologist. Phenomenology and Husserl's distinctive contribution to its advancement begin with an agnosticism about the existential character or claims to existence of objects perceived; the phenomenologist neither accepts nor rejects the claims made on his or her conscious awareness and sense apparatus. It is as if reality flows over the phenomenological subject, which in turn remains receptive and alert but non- 
judgmental: an experience and whatever it may seem to betoken is neither doubted nor even examined as to its legitimacy. It is merely regarded as an experienced claim, i.e. as one among the characteristics and features which the object in question exhibits in its presentation (Gurwitsch 1957: 380). Entities become neither the things-in-themselves, nor the forms available for the contemplation of philosophers such as Plato and his successors. Instead, 'objective entities are disclosed as correlates of acts of consciousness' (Gurwitsch 1957: 380). The turn towards consciousness which Descartes inaugurated is that turn which Husserl seeks to complete. In order to accommodate the Galilean world and to account for the reality of the external world, Descartes - Husserl thinks - ultimately conceived the ego as something existing in the world, which can be dealt with by the objective science of psychology, submitting to science modeled on physics and effectively robbing the ego - which Descartes (like Davutoğlu later) identified with the soul - of its transcendental nature. Descartes had in the end to submit to empiricism and science to speak meaningfully about exteriority, which Husserl believed is precisely what a transcendental philosophy, such as the phenomenology he desired, ought not to do; Cartesian philosophy, Husserl fears, therefore poses the risk of re-introducing the errors of the objectivists and fomenting further crisis in Europe.

The third and final epoché springs from Husserl's criticism of Descartes as inconsistent with subjectivism, and the program of phenomenology to which Descartes should have been committed. This Cartesian failing necessitated the development of a more adequate conception of mind as the basis of the transcendental subjectivist project. The third epoche is intended as the culminating completion of transcendental subjectivism. And it is the full and continuous unfolding of that subjectivism, and the exhaustive reference of all experience to consciousness that should constitute the Selbstverständnis of the Western philosopher, and become constitutive of the Western Weltanschauung.

\section{The Quranic Epoché}

The Umwelt in Davutoğlu's schema is the pre-Islamic world; the world before the Prophet Muhammad revealed the Qur'an. As the Qur'an itself describes (and Davutoğlu presumes Arabia to have been in the pre-Islamic era) the era of jahiliyyah (ignorance) was polytheistic and pagan, materialistic and uncivilised, and generally brutal and unforgiving. At the inception of Islam, the message (risalah) brought by the Prophet Muhammad was the message of monotheism (tawhild): that 'there is no god but God', implying the negation of other gods, spirits or powers. Davutoğlu finds resonance with Greek philosophy in the concept of monotheism, but differentiates Islamic monotheism from the monotheisms inherent in any preceding faith or philosophical system; he asserts (invoking Eliade 1985) the perfection of the concept of monotheism in the Qur'an, coupled with the completeness of God's omnipotence and ubiquity according to Islam (Davutoğlu 1990: 48-49). In Davutoğlu's gloss of Islamic history, at the moment of Quranic revelation Muslims escaped the Umwelt of ignorance and polytheism entering the new Muslim Lebenswelt. The Muslims became aware for the first time of the world beyond; to use the classical terms, they escaped this world (al-dunyah) for an awareness of the other world, or the hereafter (al-akhirah). In the Vienna lecture Husserl himself emphasises the inadequacy of polytheism for the departure from the Umwelt, and for transcendence:

Gods in the plural, mythical powers of every sort, are objects of the surrounding world having the same reality as animals and men. In the concept of God the singular is essential. Proper to it, from the human standpoint, is the fact that God's ontic validity and his value-validity are experienced as an absolute internal bond (Carr 1970: 288).

This description of monotheism is essentially consistent with Davutoğlu's description of tawhid, and what he terms 'ontological hierarchy.' Appropriating with some adaptation the causal and the ontological sub-status that Husserl assigned polytheism, Davutoğlu observes that 
prophecy (nubuwwah), rather than philosophy, brackets the Umwelt of the pre-Islamic Arabs delivering them to their own Lebenswelt.

Leaving constructions of the West and the notional Western worldview aside, Davutoğlu attempts to build a uniform interpretation of tawhìd, to create a consensus and a paradigmatic unity among the theological, philosophical and spiritual methodologies of Islamic thought, i.e. theology (kalām), philosophy (falsafah), and Sufism (tasawwuf) (Yusof 2007: 8). Quranic revelation framed as the Quranic epoché is the fulcrum upon which this constructive and interpretative project balances. Upon the foundational Quranic base, Islam affords the Muslims an equilibrium and certainty in life; the Qur'an is the grounds upon which Muslims are empowered to fashion and occupy the Lebenswelt. Davutoğlu in effect holds that the Qur'an impels every Muslim on to undergo the same transformation as emergent phenomenologists must: from polytheism to monotheism, from Umwelt to Lebenswelt, from naïve literalism to representations of the unseen. Both Husserl (in 1935) and Davutoğlu (in 1994) identify a crisis fomented by the collapse of the cosmic order, and the privileging of humanity to divine status. Each seeks to restore a normative structure as the solution to that crisis. The theological expression of Davutoğlu's ontological hierarchy, the Islamic doctrine of tawhid ascribes God the absolute metaphysical standing required for the Islamic counterpart to Husserl's first phenomenological reduction (epoché). The difference between the two paths to phenomenology is that Davutoğlu deems one epoché (the Qur'anic epoché) sufficiently radical and absolute to fully discharge the phenomenological impulse whilst Husserl identifies a three-stage bracketing.

Husserl lectured his contemporary, and wrote for future, philosophers in a bid to transform philosophy itself, by disseminating transcendental phenomenology (Gurwitsch 1956: 385). Davutoğlu's audience and his proselytising ambition is much larger: he seeks to challenge and transform all Muslims. He does so by propagating a unifying conception of Islam; his is a consensus-building project. Both Husserl and Davutoğlu call upon their respective readers to find and accept a personal appointment in a suitably modest position (Selbstverständnis) that is situated within an infinite span - whether that infinite span is formulated as the Weltanschauung of Reason or of Islam.

\section{The ‘Ontological Colour' of Islam}

Knowing man's ontological relationship with Allâh is the fundamental essence of the Islamic way of belief, thought and life (Davutoğlu 1994a: 60).

In Davutoğlu's system of Islamic thought the premier postulate is monotheism (tawhìd) and the implied hierarchy into which God and man are naturally, rightfully arranged; the invariant cosmic ranking produces a divide which man can never presume to cross or bridge, however awesome his progress may become. Davutoğlu denies the existence of beings of any kind inhabiting the (meta-) physical space between God and man (Davutoğlu 1994a: 60). No intermediary figure can claim any measure of divine standing; prophets including Jesus and Muhammad possessed their importance purely by virtue of their message, not an ability to mediate or intervene in the unseen world. Davutoğlu emphasises that revelation is mediated by prophecy, but that the status of revelation does not depend upon the identity of the Prophet Muhammad, who was only a man; this is also a contrast between Islam and Christianity that Davutoğlu underscores, rejecting the Christian doctrine regarding Jesus the son of God. Notwithstanding the indestructible link between God and Creation, and the reality of revelation delivered to earth, the essential premise to understanding Davutoğlu's rendering of Islam is that any comparison between God and Man is anathema, and that their respective positions in the natural hierarchy are unambiguous, fixed and eternal.

In the Islamic Weltanschauung, Davutoğlu stipulates, ontology determines epistemology, reversing what he takes to be the Western paradigm. Davutoğlu puts the point quite starkly stating that: "The principle difference between Islamic and Western Weltanschauungs is related to 
the contrast between the 'ontologically determined epistemology' of Islam and the 'epistemologically defined ontology' of the Western philosophical traditions" (Davutoğlu 1994a: 5). In assigning theoretical primacy to ontology, Davutoğlu converges with and explicitly cites a view expressed by a student of Husserl, Martin Heidegger, who wrote:

Every philosophy which revolves around an indirect or direct conception of 'transcendence' remains of necessity essentially an ontology, whether it achieves a new foundation of ontology or whether it assures us that it repudiates ontology as a conceptual freezing of experience (Heidegger 1956: 211).

Heidegger defines ontology in contradistinction to metaphysics, with the latter stating 'what beings are as beings', and the former characterising the nature, characteristics, attributes, etc., of those beings (Davutoğlu 1994a: 211). Another branch of philosophy, epistemology, is the philosophical exploration of whether humans can achieve knowledge and certainty, and, if so how and with what consequence. Davutoğlu builds the intellectual foundations of the Islamic Weltanschauung upon the ontological relationship of the individual Muslim and God, rather than on epistemology. Whereas in Islam, ontology - the hierarchy between God and man following from monotheism - is paramount, according to the contrast drawn by Davutoğlu, Western civilisation privileges epistemology which in its turn informs Western man about the ontological relationship between God and man. This sequence of primacy and chronology, with epistemology preceding ontology is the opposite of the dynamic at work in the Islamic worldview.

The inversion or overturning of the hierarchical relationship between God and man Davutoğlu terms ontological proximity, to sharpen the contrast with his own conception of ontological hierarchy. He references Hegel in support of a reading of Christian theology in which man identifies himself with God - simultaneously elevating himself and incidentally diminishing God - in a treatment that resonates with Husserl's representation of the Renaissance and the elevation of the status of man in the Galilean universe (Carr 1970: 299). Davutoğlu describes Hegel's characterisation of religion as the self-consciousness of God who has made Himself known to, and in effect commensurate with, humanity; God becomes an 'Absolute Idea, a Spirit.' (Haldane \& Simpson 1974: 348) The Hegelian universal Spirit (Geist) which particularises itself humanises God - or with the same effect apotheosises man. He labels Hegel's philosophical labours attempts to provide the justification for the Christian dogmas of incarnation, redemption, and resurrection (Davutoğlu 2000: 180).

By contrast, with tawhïd, 'Islamic ontological hierarchy and differentiation between the absolute and the relative, or between Allâh and the creature, [Islam] shapes an original Weltanschauung based on a new set of links among Allâh-man-nature' (Davutoğlu 1994a: 51). God's existence takes priority and a superior position to that of man and nature in all respects, generating a hierarchy which is the core hierarchy of the universe, and is also both descriptive and prescriptive of humanity's place within the universe. According to Davutoğlu the nearness of God to man and the boundless capacity and perfectibility of man in the Western (read: Hegelian theological) worldview is anathema to Muslim Selbstverständnis. Christian theology, he believes, also implies a philosophy of history which a Muslim could not adopt, and certainly could not take as a guide in understanding themselves or taking up their proper place in the world (Von Grunebaum 1962: 107). Davutoğlu alludes to the 'metahistorical' kingdom of God in Christianity, as opposed to the acknowledgement and fact of the historicity of Islamic civilisation and theology; he regards Islam, in contradistinction to Christianity, as historically grounded. Because Islam from the outset was and remains a faith tradition grounded in thisworldly concerns, even as it opened a window into an intangible and spiritual dimension, Davutoğlu portrays Islam as a religion that occupies a middle ground between cynical realism and hopeless idealism. He claims that Islam is immune from ahistorical flights of ideological fancy: 
Neither utopic idealism nor Machiavellistic realism has been in the mainstream of Islamic tradition. Even the concept of the golden age of Islam refers to the historical period of the Prophet and first four Caliphs unlike the metahistoric character of the Christian concept of the 'Kingdom of Heaven' (Davutoğlu 1994a: 187).

Given this time-boundedness and the contingency of the classical era and the precedent that it set for subsequent normative discourses in Islam, Davutoğlu holds that Muslims did not and do not succumb to the dangerous blandishments of utopianism (Davutoğlu 2000: 187). Whether raising the human level (in the case of utopianism) or lowering the divine (in the case of continuing charismatic prophecy), the ontological hierarchy he treats as an axiom of his interpretive project is, he believes, absolute.

Davutoğlu and Husserl agree on the ethical implications of the human position in a hierarchical order. The causes of the crisis of humanity noted by Husserl are the same causes that concern Davutoğlu, although the latter expresses these concerns and the crisis itself through a religious rather than a philosophical register. The perception that Westerners (or their protégés in Muslim societies) individually and/or as a species place themselves close to God, to the end of perfecting themselves or becoming god-like, is the common cause. The greatest concern Davutoğlu expresses in practical terms regarding the levelling of that primary relationship is the loss of 'ontological security' (Deniz 2002: 37), a kind of security which he deems a basic human need; such security is the certain knowledge of the proper human role in the cosmic order, and the feeling of safety that accompanies that certainty. Davutoğlu depicts the Islamic paradigm as one stabilised by means of the Qur'an, 'around the fundamental principles of the ontological unity, absoluteness, and hierarchy of Allâh' (Davutoğlu 1994a: 75). The particularised identity of God he finds in a Hegelian Christian theology is, he postulates, alien to Muslim Selbstverständnis. Davutoğlu's theoretical project sets aside and distinguishes itself from the Western ontological proximity to God in order to embrace a distinctively Islamic phenomenology, and to adopt a consciousness suffused with ontological colour.

\section{Knowledge, History, and Utopia}

With the first, the axiomatic Islamic moment - Qur'anic revelation - the existence and ontological standing of God was established, and Davutoğlu finds the grounding for the ontological hierarchy that is the foundation of the Islamic Weltanschauung. Taking up the task of developing a distinctively Islamic epistemology Davutoğlu concerns himself with the foundation of knowledge after that axiomatic moment and beyond direct Qur'anic reference. Monotheism and all its implications are privileged as products of revelation (wahy) (Davutoğlu 1994a: 75) which Davutoğlu considers unimpeachable, as the Qur'an is (according to Muslim belief) the literal word of God, and hence definitive proof of God's existence and unicity (tawhid). Deductive, rational, or evidential proofs along the lines of Pascal or Descartes, for example, are therefore ruled theoretically (and practically) unnecessary. Davutoğlu holds that there could have been no understanding of tawhïd independent of the Quran, no exit for the Muslims and their predecessors from the Umwelt, and no entry into the Lebenswelt without Qur'anic revelation.

In his political theory, Davutoğlu undertakes the goal, drawing and underscoring a line between Islamic and Western understanding of the political community and the social contract. He criticises as pre- or anti-historical social contract theory and the state of nature from which the civil state evolved, according to European social contract philosophers such as Thomas Hobbes and Jean Jacques Rousseau; the hypothetical character of that pre-political state of nature typically but not exclusively replicated in the Western contractarian tradition of political theory is one that Davutoğlu reads as requiring a radical break between past and present: a break which he believes generates an unhealthy fixation upon an exaggeratedly glorious future, and an imaginative disregard for historicity and contingency. Davutoğlu suggests that the 
secular and Western idea of progress rests upon a similar and similarly artificial break from history. By contrast, 'the Muslim mind assumes that the ethical ideal and perfectibility are reflected in the continuity of the eternal tradition from the past through the present to the future' (Davutoğlu 2000: 197).

Davutoğlu summarises the Islamic paradigm in chronological terms, beginning with revelation; the rational, human re-interpretation of revelation by means of community consensus; 'the historicity of both the revealed text and the religious leadership of prophecy'; and, the link between 'the ontological and socio-political levels of existence of the individual'. The rational legitimation of the faith at each stage obviated the need for a clergy and, in turn, for the division of religious and political affairs (Davutoğlu 2000: 184). As is commonly argued in Arab political thought over the last three decades clerical venality gave rise to the historical necessity for secularism (Morrison 2013: 65-67); secularism offered liberation from the ecclesiastical class. However Davutoğlu asserts that since such a class never arose in Islam, obviating secularism and the need for the exclusion of religion from the socio-political sphere (Davutoğlu 2000: 184).

The essential contention of this article, and the reason for juxtaposing Edmund Husserl's Vienna lecture with Ahmet Davutoğlu's dissertation is the isolation and description of the phenomenological impulse; a cohesive elaboration of the Islamic Weltanschauung in the words selected and ordered by one Muslim thinker; and an enquiry into whether Islam so set out is an enactment of the phenomenological impulse. If it is such an enactment, then Muslim Selbstverständnis and the finite proportion of an infinite task condign to a mortal, created being (such as a person) is tantamount to a theologically-inflected call to phenomenology; Husserl issued the same summons, with philosophy standing in place of theology. On this reading of Islam, each figure offers one of two possible correctives to the crisis of humanity; a crisis which originated in Europe but which spread throughout the Muslim world by means of Muslim and non-Muslim modernists, modernisers, and those otherwise subscribing uncritically to modern science or implicated in scientism.

As a committed Muslim Davutoğlu opts for a phenomenological reading of his religion that endeavours to build a consensus suffused with ontological colour. Husserl, a twentiethcentury subjectivist, declines deism but - with a conviction and sincerity equalling that of Ahmet Davutoğlu - he recommends the same phenomenological response to the crisis. Where Husserl leads the philosophically-inclined reader through a conversion requiring three epoché Umwelt to Lebenswelt, the Cartesian moment of consciousness, and his own post-Cartesian corrective - Davutoğlu stages for the Muslim reader a single comprehensive phenomenological reduction that collapses three epoché into one: the Quranic epoché. At different speeds and historical moments, and among different populations and geographic regions, the two distinct paths broken by these two figures terminate with logically identical conclusions: the postulation of an alternative, intangible reality; the equation of accessible reality to that which is conscious (i.e. to consciousness); and the effectual resolution of a contemporary state of ontological crisis wrought by humanity's proclivity for self-aggrandisement and overweening intellectual ambitions.

As an interpretive but also a political (broadly understood) enterprise Davutoğlu's 1994 book aims to minimise differences within Islamic traditions and to construct (or putatively to discover, reveal or remember) unanimity whilst intensifying the contrast between Islamic and Western/Christian spiritual and intellectual commitments even as he quotes and appropriates particularistic elaborations of Christian philosophical concepts - for example those formulated by the German philosophers Hegel, Husserl and Heidegger. Eschewing an empirical basis for their authorial authority, and relegating science to the category of quod erat non demonstrandum, Husserl and Davutoğlu each adopt the vocabulary and analysis of Weltanschauungen for apparently similar methodological and substantive reasons. And even as one speaks to the self-subscribed successors to an ancient Greek intellectual legacy, and the 
other to the Muslim faithful, each thinker seeks to situate himself and his respective reader in a Selbstverständnis that is seemly and appropriate - to a finite participant in an infinite task.

\section{References}

Biemel, W. 1962. Krises de europäisichen Wissenschaften und die transzendentale Phänomenologie Edmund Husserl 1859-1938 [Crisis of European Humanity and the Transcedental Phenomenology of Edmund Husserl]. The Hague: Martinus Nijhoff.

Carr, D. (Transl.). 1970. The Crisis of European sciences and transcendental phenomenology: An introduction to Phenomenological Philosophy. Evanston, IL: Northwestern University Studies in Phenomenology \& Existential Philosophy.

Davutoğlu, A., 1994a. Alternative paradigms: The impact of Islamic and Western Weltanschauungs on Political Theory. Lanham, MD: University Press of America.

Davutoğlu, A. 1994b. Civilizational transformation and the Muslim World. Kuala Lumpur: Mahir Publications.

Davutoğlu, A. 2000. Philosophical and institutional dimensions of secularisation: A comparative analysis. In Azzam Tamimi \& John L. Esposito (eds.). Islam and Secularism in the Middle East, pp. 170-208. London: Hurst and Co.

Davutoğlu, A. 1999. Rewriting contemporary Muslim politics: A twentieth-century periodization. In Fred R. Dallmayr (Ed.). Border Crossings: Toward a Comparative Political Theory, pp. 89-118. Lanham, MD: Lexington Books.

Davutoğlu, A. 2001. Stratejik derinlik: Türkiye'nin uluslararası konumu [Strategic Depth: Turkey's International Relations] Istanbul: Küre Yayınları.

Deniz, Faruk. 2002. Küresel bunalım: 11 Eylül konuşmaları [Global Crisis: 11 th of September Conversations] Istanbul: Küre Yayınları.

Eliade, M. 1985. The history of religions: Retrospect and prospect. In Joseph Kitagawa (Ed.). New York: Macmillan.

Gurwitsch, A. 1956. The last work of Edmund Husserl. Philosophy and Phenomenological Research 16(3): 380-393.

Gurwitsch, A. 1957. The last work of Edmund Husserl. Philosophy and Phenomenological Research 17(3): 370-398.

Haldane, E.S. \& Frances H. Simson (Transl.). 1974. Hegel's lectures on the History of Philosophy. London: Routledge and Kegan Paul.

Hammond, M. \& Jane Howarth \& Russell Keat. 1991. Understanding phenomenology. Oxford: Basil Blackwell.

Heidegger, M. 1956. Existence and being. In W. Brock (Ed.). London: Vision Press.

Husserl, E. 1981. In Peter MacCormack (Ed.). Shorter works. Notre Dame, IN: University of Notre Dame Press.

Mardin, Ş. 1989. Jön Türkler'in siyasi fikirleri 1895-1908 [Young Turks' Political Thought 18951908]. Istanbul: İletişim Yayınları.

Morrison, S. 2013. Secularism revised: Arab Islam, religious freedom and wquidistance. Kuala Lumpur: The Other Press.

Von Grunebaum, G.E. 1962. Modern Islam: The search for cultural identity. Connecticut: Greenwood Press.

Yusof, D.M. 2007. Davutoglu's paradigm, winkel's epistemé, and political science in Malaysia. Asian Journal of Social Science 35: 6-18. 